\title{
Projected Changes in Stream System Nitrogen Runoff Associated with a Mature Cellulosic Ethanol Industry in the Southeastern United States
}

\section{Introduction}

Rapid growth of the United States' (US) biofuel industry in the mid-2000s was largely driven by the Renewable Fuel Standard (RFS) established by the US Energy Policy Act of 2005. The RFS required domestic transportation fuel to contain a specified volume of biofuels, with the quantity increasing annually over a 15 year period (US Congress, 2005). The RFS was expanded under the US Energy Independence and Security Act of 2007 (EISA) to 136 billion liters per year (bly) by 2022, including 79.49 bly derived from cellulosic or other non-grain feedstock sources (US Congress, 2007). However, the US Environmental Protection Agency (EPA) has waived or reduced the expanded RFS mandate (RFS2) every year since its 2010 inception in response to downward-adjusted cellulosic-derived fuel production projections. ${ }^{1}$ The widening distance between the productive capacity of an advanced biofuel industry and the RFS2-mandated production levels is increasingly cited as a rationale for revising or repealing the mandate. The continuing debate over the RFS2 provides an opportunity to consider not only the feasibility of dramatic increases in the production of advanced biofuels in the near term, but also the secondary effects of such production, on water quality impacts following the large-scale conversion of agricultural lands to feedstock production.

Current grain-based ethanol production is near the conventional biofuel 56.78 bly mandate for 2022 (Schnepf and Yacobucci, 2013). However, achieving the production mandates for cellulosic ethanol will require significant advances in production capacity, including the

\footnotetext{
${ }^{1}$ The disposition of the 2014 standard remains unclear. In late 2013, the EPA proposed to lower the 2014 mandate from 6.62 billion to 64.35 million liters (US EPA, 2013).
} 
construction of scores of feedstock pre-processing sites and bio-refinery facilities (National Research Council, 2011). Meeting increased demand for energy crops will likely involve extensive conversion of previously uncultivated land, fallow agricultural land, pastureland, or land set aside for conservation (de la Torre Ugarte et al., 2007). These land use changes could substantially increase total agricultural land in production and nutrient applications, because many of these lands are not currently intensively managed with fertilizer (Robertson et al., 2010; Perlack and Stokes, 2011; Demissie, Yan, and Wu, 2012). On the other hand, conversion of crop land to switchgrass production could reduce nutrient applications given that switchgrass requires less fertilizer than many of the crops presently grown in the southeastern US (de Koff and Tyler, 2011). Thus, changes in agricultural land use and concomitant changes in fertilizer applications could engender significant changes in the level and spatial pattern of the runoff of nitrogen $(\mathrm{N})$ and phosphorous $(\mathrm{P})$ into local and regional surface stream and river systems. Excess $\mathrm{N}$ and $\mathrm{P}$ in hydrologic systems may cause eutrophication leading to algae blooms, reductions in species diversity, and diminished recreational enjoyment and ascetic appeal (Donner, Kucharik, and Foley, 2004; Costello et al., 2009). Extreme cases of eutrophication cause hypoxia, a condition whereby dissolved oxygen levels impair aquatic life (Costello et al., 2009).

Policy goals and the political will to implement them, the natural distribution of land suitable for biomass production, production costs, energy prices, and the site selection activity of cellulosic ethanol production facilities will drive changes in land use and eventually water quality. However, it remains unclear what industrial geography will emerge, how the distribution of cellulosic refineries will impact land use change through backward linkages to feedstock 
production systems, and where and to what extent water quality indicators will be impacted through changes in nutrient runoff.

Forecasting the impacts of policies supporting the development of a cellulosic ethanol industry on land use change and water quality entails determining (1) cost-minimizing biorefinery locations; (2) the geographic distribution of associated land use changes and crop mix; (3) the resulting changes in the spatial distribution and intensity of fertilizer nitrogen (N) application; and (4) the extent to which changes in the spatial pattern of $\mathrm{N}$ application cause changes in nitrogen runoff into hydrologic systems. This study integrates the Biofuels Facility Location Analysis Modeling Endeavor (BioFLAME) site selection model (Wilson, 2009) with the Spatially Referenced Regressions on Watershed Attributes (SPARROW) hydrologic water quality model (Schwarz et al., 2006) to examine the ex-ante impact of changes in agricultural $\mathrm{N}$ runoff into surface water associated with the conversion of crop and pasture land to feedstock production. The regional focus is the Southeastern-Atlantic, Eastern Gulf, and Tennessee River (SAGT) basin (Figure 1). Research by the US Department of Agriculture (USDA) suggests that the southeastern US could produce as much as 41.6 billion of the 79.5 bly annual production mandate for advanced biofuels with full-scale implementation of the RFS2 (USDA, 2010a). The SAGT basin was selected because it forms a hydrologic system contained entirely in the southeastern US (Figure 1). The key factor examined is the impact of changes in agricultural nitrogen fertilizer use driven by feedstock demand on total N runoff into the SAGT basin.

Switchgrass (Panicum virgatum), a native perennial grass considered favorable for cellulosic ethanol production in the southeastern US (Wright, et al., 2010), is the energy feedstock analyzed. Planting switchgrass on land where $\mathrm{N}$ fertilizer was not intensively applied 
could increase nutrient runoff into streams, rivers, and reservoirs. On the other hand, the conversion of land used to produce crops with high $\mathrm{N}$ fertilizer demand to switchgrass production may reduce nutrient runoff into waterways (McIsaac, et al., 2010; Robertson et al., 2010; Smith et al., 2013). This analysis compares initial water quality indicator levels with industry configurations and attendant land use changes evaluated under different policy scenarios, ranging from $22 \%$ fulfillment of the RFS2 mandate to the full attainment and the resulting levels of cellulosic ethanol that could be produced in the southeastern US. The cellulosic ethanol production levels analyzed $(22 \%, 31 \%, 50 \%$, and $100 \%$ of the RFS2 mandate) reflect the possibility that the mandate may be reduced or only be partially realized, or, alternatively, the growth of an advanced biofuel industry over time. The $22 \%$ corresponds with an estimated farm gate price of $\$ 85 \mathrm{t}^{-1}\left(\$ 94 \mathrm{Mt}^{-1}\right)$ for switchgrass reported by the National Research Council (2011). The 31\% target corresponds with a price of $\$ 100 \mathrm{t}^{-1}\left(\$ 110 \mathrm{Mt}^{-1}\right)$ which is an upper bound limit of a study by Khanna et al. (2011a) and the approximate midpoint of a range of expected prices estimated for the Midwestern US (Khanna et al. 2011b).

\section{Methods and Models}

\subsection{Least-Cost Cellulosic Biorefinery Location and the BioFLAME Site Selection Model}

Low-cost production and reliable acquisition of feedstock is a prerequisite for the sustainable development of a commercial cellulosic ethanol sector (USDA, 2011a). The willingness of farmers to supply biomass energy crops depends on the opportunity costs of alternative land uses (Jensen et al., 2007). Due to the bulkiness and low energy density of cellulosic biomass, harvest, storage, and transportation costs are high relative to other 
agricultural commodities (English et al., 2013). Choosing profit-maximizing facility locations involves a tradeoff between transport costs of inputs and the costs of transporting fuel to intermediate blenders and final consumers (McCann, 2013). Ethanol facilities are characterized as supply-oriented firms because total costs are dominated by expenditures on feedstock procurement (Shapouri and Gallagher, 2005). Supply-oriented firms tend to locate near inputs to minimize procurement costs (Lambert and McNamara, 2009). Feedstock accessibility is a dominant location determinant with respect to grain-based ethanol production and prospective refinery sites (Lambert et al., 2008). Biorefineries using cellulosic feedstock are also likely to locate close to biomass producers because of the high storage and transportation costs associated with feedstock materials (Larson et al., 2005).

BioFLAME (Wilson, 2009; Wilson et al., 2011) determines least-cost locations for biofuel facilities and attendant land use changes due to industry feedstock demand using feedstock yield potential and land use patterns, (National Agricultural Statistical Service [NASS], 2008; SSURGO, 2009), crop prices (USDA, 2009), and transport costs and road networks (Brechbill, Tyner, and Ileleji, 2008; ASAE, 2009; ESRI, 2005). The model is calibrated for the southeastern US (including Alabama, Arkansas, Kentucky, Mississippi, Georgia, Tennessee, North Carolina, South Carolina, and Virginia), and has been previously used to explore the optimal siting and economic impacts of preprocessing facilities (Wilson, 2009; English et al., 2013; Lambert et al., 2014). BioFLAME operates on GIS architecture consisting of three components—site suitability, feedstock availability, and land conversion. Road networks, transmission lines, and other geo-spatial layers are used to identify candidate cellulosic refinery locations (ESRI, 2005). Given an annual target output level of an individual facility, 
BioFLAME estimates: 1) the cost minimizing locations where cellulosic feedstock would be sourced to supply the facility, 2) the annual cost of procuring and transporting feedstock, 3) the number of facilities a region can support (based on existing infrastructure and feedstock supply potential of arable land), and 4) the area under conventional crop production converted to switchgrass. Area in forest land is held constant. The BioFLAME algorithm ranks potential facility locations based on plant-gate feedstock costs, including procurement plus transport costs. To estimate procurement costs, county-level crop budgets, crop area, and crop commodity prices are used to calculate a break-even price at which farmers would be indifferent between planting conventional crops or producing dedicated biomass energy crops. The conventional crops included in the current version of BioFLAME include corn, soybeans, wheat, barley, oats, hay and pastureland, sorghum, and cotton. Land rent values for the main agricultural activities are disaggregated by county for row crops, hay, and pasture. The opportunity costs for pasture are estimated using USDA/NASS county-level pasture land rent data (USDA/NASS, 2013).

The BioFLAME model was calibrated using 2009 crop production and environmental data (USDA, 2009; SSURGO, 2009; USDA, 2011b) from which land use changes and changes in water quality associated with the RFS2 are estimated. The spatial distribution of the cropland data layer was determined by upscaling NASS 2009 Cropland Data Layer (measured in 30 m by $30 \mathrm{~m}$ pixels) into a tessellation comprised of 82,828 hexagons, with each hexagon a $5 \mathrm{~km}^{2}$ area. These hexagons are the fundamental spatial units of BioFLAME. Each $5 \mathrm{~km}^{2}$ unit represents a candidate facility location and the area of agricultural land that could be converted to dedicated energy crop production. Using the USDA 2009 crop market prices (USDA, 2009), the site 
locator model estimates the price point at which a farmer or landowner would convert land allocated to conventional crops to switchgrass production.

For transportation costs, the shortest path to every potential feedstock supply unit along the transportation network is determined and used to generate a least-cost transportation surface. A hierarchy of primary, secondary, and tertiary roads (categorized by the speed limits of each road type) generates arcs between supply nodes. The feedstock supply analysis subsequently evaluates the costs of siting a facility among the set of all candidate sites in a region. The sum of transportation and farm gate costs are minimized at preferred sites.

Individual facility output levels are $284 \mathrm{mly}$ (millions of liters $\mathrm{yr}^{-1}$ ), which is $94 \%$ the full operating capacity of engineering specifications (Humbird et al., 2011). Thus, producing 41.64 bly of cellulosic ethanol in the southeastern region would require 147 facilities. Once a least-cost site is determined, the feedstock area associated with that location is eliminated before the next iteration, effectively simulating a contract between farmers and the biorefinery for switchgrass production. This step forces refineries that subsequently enter to look elsewhere for low cost feedstock sites. This iterative process continues until all 147 locations are determined. Associated changes in the spatial distribution of agricultural crops and land converted to biomass production are estimated following the location of all facilities.

The quantity of $\mathrm{N}$ applied to crops is taken from the regional crop budgets developed for the POLYSYS agricultural sector model (De La Torre Ugarte et al., 1997; De La Torre Ugarte et al., 2007). The corresponding quantities of $\mathrm{N}$ applied to crops are determined using the crop production distribution required by biorefinery feedstock demand. There are no region-specific $\mathrm{N}$ application recommendations for switchgrass reported in the literature. The quantity of $\mathrm{N}$ applied 
to switchgrass was calculated using a uniform application rate of $67.25 \mathrm{~kg} \mathrm{ha}^{-1}$ (McKinley and Gerloff, 2010). At the time the crop production GIS data layers were developed for BioFLAME, the USDA Census of Agriculture did not distinguish between pastureland and land cultivated in hay. This data limitation precluded differentiating hay land from pastureland and calculating the quantity of $\mathrm{N}$ applied to these land uses separately. Thus, the hay $\mathrm{N}$ fertilizer rate is used to proxy $\mathrm{N}$ applied to pasture. Since less $\mathrm{N}$ is typically applied to pasture than to hay, the estimated effects on water quality due to the conversion of hay and pasture land represents an upper bound.

\subsection{Nutrient Runoff, Water Quality and the SPARROW Model}

The US Geological Survey's (USGS) SPARROW water quality model is a statistical mass balance hydrologic model that estimates the major sources and environmental factors determining the long term supply, transport, and fate of surface water systems (Smith et al., 1997). Separate land and hydrology components generate estimates of pollution delivery rates from point and diffuse sources to stream reaches and downstream receiving bodies. Parameter estimation using stream water quality records, spatially explicit data on reservoirs, and climatic and geological features facilitates a statistical approach for testing hypotheses about different pollution sources and primary transport processes at larger spatial scales (Schwarz et al., 2006).

The SPARROW model generates ex-ante forecasts of the impacts land use changes have on water quality through changes in point and non-point source nutrient runoff variables. SPARROW uses nonlinear least squares regression to explain nutrient mass balance in watershed networks as a function of anthropogenic, geographic, and climatic factors. The SPARROW model has been used extensively to forecast changes in nutrient runoff in North Carolina (Ator et 
al., 2011), New England and the Mid-Atlantic states (Moore et al., 2011), and the Tennessee River basins (Hoos and McMahon, 2009).

The South Atlantic-Gulf-Tennessee basin system SPARROW model (SAGTSPARROW, Hoos and McMahon, 2009) is used to examine the impacts land use changes resulting from a mature cellulosic biofuel industry could have on water quality in the southeastern US. The SAGT region is $802,723 \mathrm{~km}^{2}$. The SAGT database, developed by Hoos et al. (2008), includes $n=321$ USGS monitoring sites that collect data on water flow, nutrient runoff, and sedimentation changes in the SAGT basin. Areal data from the corresponding watershed units (as described in Seaber et al., 1987), such as urban, residential, agriculture, or forest land use patterns, pollution point sources, system-wide nutrient runoff from agriculture and urban activities, and geophysical features are used as regressors to fit nitrogen runoff data collected at the monitoring stations. Nitrogen runoff predictions are generated using the stream network configuration of the basin (Figure 1). Runoff predictions are estimated for each watershed comprising the SAGT basin ( $N=8,321$ watersheds).

Schwarz et al. (2006), Smith et al. (1997), Quian et al. (2005), and Hoos and McMahon (2009) provide details on estimation and calibration of the SPARROW model. The general structure of SPARROW is:

$$
y_{i}=\left[\begin{array}{c}
\sum_{j \in J(i)} y_{j} \cdot A\left(Z_{i}^{S}, Z_{i}^{R} ; \theta_{S}, \theta_{R}\right) \\
+\sum_{m=1}^{M_{S}} \beta_{m} \cdot S_{m, i} \cdot D_{m}\left(Z_{i}^{D} ; \theta_{D}\right) \cdot A\left(Z_{i}^{S}, Z_{i}^{R} ; \theta_{S}, \theta_{R}\right)
\end{array}\right]+\varepsilon_{i},
$$

where: 
$y_{i}$ is the nutrient runoff in watershed $i=1, \ldots 8,321$ of the SAGT basin $\left(\mathrm{kg} \mathrm{yr}^{-1}\right)$ (observed data);

$S_{m, i}$ is nutrient source $m$, watershed $i$ (observed data);

$Z^{D}$ are physical landscape characteristics (observed data);

$Z^{S}$ are physical stream characteristics (e.g., depth and velocity) (observed data);

$Z^{R}$ are reservoir variables (e.g., reservoir hydraulic loading) (observed data);

$J(i)$ indexes the upstream watersheds flowing into watershed $i$;

$D_{m}\left(Z_{i}^{D} ; \theta_{D}\right)$ is a nutrient delivery function;

$A\left(Z_{i}^{S}, Z_{i}^{R} ; \theta_{S}, \theta_{R}\right)$ are stream and reservoir attenuation functions;

$\left(\theta_{D}, \theta_{S}, \theta_{R}\right)$ are parameters regulating the transport and movement of nutrients between watersheds (estimated);

$\beta_{m}$ are delivery ratio parameters characterizing the contribution of nutrient sources to stream runoff (estimated); and

$\varepsilon_{i}$ is an independent and identically distributed random disturbance with an expected value of zero and a constant variance.

Physical landscape characteristics include soil permeability (in natural logs), bedrock depth (in natural logs), mean annual precipitation (in natural logs), the percent of a watershed included in a hydrological landscape region (HLR) (five HLR regions cover the SAGT area), and the percent of a watershed included in an ecoregion (six ecoregions define the SAGT basin). Physical stream attributes are measured by (1) the segment travel time for small streams (mean 
flow $\left.<2.8 \mathrm{~m}^{3} \mathrm{sec}^{-1}\right)$, and (2) the segment travel time for larger streams $\left(2.8 \mathrm{~m}^{3} \mathrm{sec}^{-1} \leq\right.$ mean flow $\left.<28 \mathrm{~m}^{3} \mathrm{sec}^{-1}\right)$. Loss rate coefficients were estimated for small $\left(<2.8 \mathrm{~m}^{3} \mathrm{~s}^{-1}\right)$ and intermediate $\left(2.8-280 \mathrm{~m}^{3} \mathrm{~s}^{-1}\right)$ streams, and are expected to be positive but lower in magnitude as stream sizes increase (Alexander et al., 2000). Land-to-water delivery factors $\left(D_{m}\left(Z_{i}^{D} ; \theta_{D}\right)\right)$ are modeled with an exponential kernel; $\exp \left(\theta_{D}^{\prime} Z^{D}\right)$. Reach attenuation factors $\left(A\left(Z_{i}^{S}, Z_{i}^{R} ; \theta_{S}, \theta_{R}\right)\right)$ are modeled as an exponential decay; $\exp \left(-\theta_{S}^{\prime} Z^{S}\right)$ or $\exp \left(-\theta_{R}^{\prime} Z^{R}\right)$. The estimated reservoir loss coefficient summarizing the mean water column length from which $\mathrm{N}$ is removed annually is expected to be positive (Schwarz et al., 2006).

Nitrogen runoff sources $\left(S_{m, i}\right)$ include; (1) $\mathrm{N}$ mass permitted in waste water discharge, (2) inorganic $\mathrm{N}$ deposition, (3) impervious surface area, (4) commercial $\mathrm{N}$ fertilizer applied to agricultural land, and (5) N mass from livestock manure (Hoos and McMahon, 2009). These variables are of interest to policymakers and analysts because they are anthropogenic sources of pollutants. In this application, changes in the contribution of $\mathrm{N}$ from applied agricultural fertilizer $\left(S_{F E R T, i}\right)$ are simulated, holding contributions from the other sources constant. The source variable for $\mathrm{N}$ applied to agricultural land used to calibrate the baseline SAGT SPARROW model was calculated using 2002 county-level fertilizer expenditure data and 2001 USGS National Land Cover Database (NLCD) land cover classifications by Ruddy et al. (2006). This variable is an aggregate of $\mathrm{N}$ applied to all types of agricultural land, including dominant row crops, orchards, agroforestry, vegetables, hay and pasture, vineyards, row crops, small grains, and cereals. The changes in $\mathrm{N}$ fertilizer applied in each watershed, the changes in $\mathrm{N}$ runoff due to changes in emissions from agriculture (i.e., $\mathrm{N}$ fertilizer use) are approximated by adjusting $S_{F E R T, i}$ to reflect the conversion of agricultural land to the production of switchgrass. 
The statistical relationship between observed agricultural $\mathrm{N}$ fertilizer applications, $\mathrm{N}$ runoff, and $\mathrm{N}$ concentrations in streams is estimated and then used to forecast $\mathrm{N}$ runoff into each watershed.

Rewriting the non-linear model of equation 1 as a generalized function, the predicted values of the baseline regression are,

$$
\hat{y}_{0 i}=g\left(S_{F E R T, i} \cdot \hat{\beta}_{F E R T} ; S_{m-1, i} \hat{\beta}_{m-1}, Z_{i} \hat{\theta}\right)
$$

where $\hat{y}_{0 i}$ is the baseline predicted value for stream $\mathrm{N}$ runoff in watershed $i=1, \ldots 8,321 ; g(\cdot)$ is the function of equation $1 ; S_{F E R T, i}$ is the applied $\mathrm{N}$ fertilizer to agriculture in watershed $i$ used in the calibration step of SPARROW; $\hat{\beta}_{F E R T}$ is the estimated regression coefficient for $\mathrm{N}$ applied to agricultural land; $S_{m-1}$, are all other source variables excluding applied $\mathrm{N}$ fertilizer; $\hat{\beta}_{m-1}$ are the coefficients of all other $\mathrm{N}$ sources; and $Z_{i}$ are all other covariates with corresponding parameters $\hat{\theta}$.

The baseline share of $\mathrm{N}$ runoff into the system attributable to agriculture sources is

$$
\% N_{F E R T, i}^{0}=100 \times S_{F E R T, i} \cdot \hat{\beta}_{F E R T} / \sum_{m=1}^{M_{S}} S_{m, i} \cdot \hat{\beta}_{m}
$$

2.3 Policy Scenarios, Land Use Changes, Applied Fertilizer, and Water Quality

We examine four levels of cellulosic ethanol production for the SAGT basin: 3.97, 7.12, 11.92, and 18.12 bly to simulate the impacts of changes in agricultural $\mathrm{N}$ use corresponding with 
landscape reconfigurations on water quality. Each production level corresponds with achieving $22 \%, 31 \%, 50 \%$, and $100 \%$ of the anticipated 41.64 bly of production in the southeastern US, respectively, given the production capacity of individual cellulosic facilities and feedstock availability in the basin ${ }^{2}$. The RFS2 mandate was not in force when the baseline covariates and stream runoff data were generated. We therefore maintain an important assumption that the calibrated SPARROW model represents pre-RFS2 water quality equilibrium conditions. By perturbing the agricultural fertilizer source variable $\left(S_{F E R T, i}\right)$, holding all other variables constant and under equilibrium conditions (i.e., the estimates of the calibrated model: $\hat{\beta}, \hat{\theta}$ ), we gauge the impact of meeting RFS2 goals on stream N runoff from changes in fertilizer application relative to a counterfactual baseline (i.e., stream $\mathrm{N}$ runoff absent the policy, $\hat{y}_{0 i}$ ).

Land use changes driven by industry demand for biomass feedstock enter the calibrated SPARROW model as changes in $S_{F E R T, i}$ to simulate impacts on $\mathrm{N}$ sources. Aggregate fertilizer applied by the agricultural sector $\left(S_{F E R T, i}\right)$ is composed of fertilizer applied to the key field crops analyzed here $\left(S_{F E R T, i}^{F l d C r o p}\right)$, plus nitrogen applied by all other agricultural activities $\left(S_{F E R T, i}^{\text {OthAct }}\right)$ :

$$
S_{F E R T, i}=S_{F E R T, i}^{\text {OthAct }}+S_{F E R T, i}^{\text {FldCrop }}
$$

Changes in the baseline aggregate agricultural fertilizer source variable $\left(S_{F E R T, i}\right)$ are a function of the baseline field crop $\mathrm{N}$ demands and the new crop demand for $\mathrm{N}$ following policy

\footnotetext{
${ }^{2} 22 \%$ corresponds with a $\$ 94 \mathrm{Mt}^{-1}\left(\$ 85 \mathrm{t}^{-1}\right)$ switchgrass price, and $31 \%$ corresponds with a $\$ 110 \mathrm{Mt}^{-1}\left(\$ 100 \mathrm{t}^{-1}\right)$ switchgrass price.
} 
implementation. Deviations from the baseline aggregate are simulated holding $S_{F E R T, i}^{\text {Oth } A c t}$ constant and perturbing $S_{F E R T, i}^{\text {FldCrop }}$. For example, define $S_{F E R T, i}^{T}$ as the quantity of N applied in watershed $i$ under target production level $T(=22 \%, 31 \%, 50 \%$, and $100 \%)$, noting that $T=0$ indicates the baseline kilograms of nitrogen applied in the initial equilibrium. A relative change in aggregate fertilizer applied is:

$$
S_{F E R T, i}^{T>0}=S_{F E R T, i}^{O t h A c t}+\left(1+\epsilon_{i}\right) \cdot S_{F E R T, i}^{\text {FldCrop }},
$$

where:

$$
\epsilon=\left[\frac{\left(N_{i}^{T>0}-N_{i}^{T=0}\right) / N_{i}^{T=0}}{\left(N_{i}^{T>0}-S_{F E R T, i}^{\text {FldCrop }}\right) / S_{F E R T, i}^{\text {FldCrop }}}\right],
$$

and $N_{i}^{T}$ is the total nitrogen applied in watershed $i$ to the field crops estimated with the 2009 USDA cropland data layer used in BioFLAME (e.g., $N_{i}^{T}=\sum_{k=1}^{9} N_{i, k}^{T}$, with $k$ indexing the eight conventional crops plus switchgrass). The components of the applied fertilizer variable $\left(S_{F E R T, i}^{\text {OthAct }}\right.$ and $\left.S_{F E R T, i}^{\text {FldCrop }}\right)$ were unavailable in the SAGT data base. Therefore, NASS 2002 county level crop production data was used as a proxy such that $S_{F E R T, i}^{F l d C r o p}=\sum_{k=1}^{8} N_{i, k}^{2002}$, where $N_{i, k}^{2002}$ are the applied nitrogen from the POLYSYS budgets containing region-specific fertilizer rates and the county level crop production data. In $22 \%$ percent of the watersheds, $S_{F E R T, i}<S_{F E R T, i}^{\text {FldCrop }}$. 
In these cases, we set $S_{F E R T, i}^{\text {OthAct }}=0$ and $S_{F E R T, i}=S_{F E R T, i}^{\text {FldCrop }}$. This provided a benchmark from which to compare changes in land use generated by the site locator model with the initial state documented in the 2002 USGS fertilizer use data. Blackhurst et al. (2010) also used a proportional adjustment procedure to benchmark USGS water use data with USDA crop water demand estimates. The denominator of $\epsilon$ adjusts for differences in the time periods the fertilizer data was compiled by Ruddy et al. (2006) for SPARROW and BioFLAME (2009 USDA/NASS data). The factor is a decimal percent change when divided by 100 . When $T=0, \epsilon=0$, and $S_{F E R T, i}^{T>0}=S_{F E R T, i}($ the baseline applied nitrogen level). When $\epsilon>0(\epsilon<0)$, applied fertilizer increases (or decreases) following changes in the agricultural landscape due to feedstock demand by biorefineries.

The updated fertilizer source variable, $S_{F E R T, i}^{T}$, replaces the $S_{F E R T, i}$ variable used to calibrate SPARROW (Equation 2), yielding predicted values for nutrient concentration in watershed $i\left(\hat{y}_{i}^{T}\right)$ for the four production levels:

$$
\hat{y}_{i}^{T}=g\left(S_{F E R T, i}^{T} \cdot \hat{\beta}_{F E R T} ; S_{m-1, i} \cdot \hat{\beta}_{m-1}, Z_{i} \cdot \hat{\theta}\right), T=22,31,50 \text {, and } 100 \% \text { targets. }
$$

The hypothesis tested against the calibrated SPARROW model is: changes in agricultural land use resulting from cellulosic industry developmental policies will not impact $\mathrm{N}$ runoff in the SAGT basin's hydrologic system. To test this hypothesis $\left(\mathrm{H}_{0}: \Delta y=0\right)$, we estimate the effect of the conversion of agricultural land to switchgrass production on $\mathrm{N}$ applied as fertilizer at the watershed level (the source variable $S_{F E R T, i}$ in equation 1), and how changes in $\mathrm{N}$ applied as 
fertilizer alters the estimated $\mathrm{N}$ runoff $(\hat{y})$. Rejection of the null hypothesis, i.e., $\Delta y \neq 0$, following policy implementation suggests that the RFS2 policy impacts these indicators in some direction.

Changes in the aggregate share of the fertilizer source variable to nutrient concentration is calculated similarly by replacing the original fertilizer application data with the updated variable, $S_{F E R T, i}^{T}$;

$$
\% N_{F E R T, i}^{T}=100 \times\left(S_{F E R T, i}^{T} \cdot \hat{\beta}_{F E R T} /\left[S_{F E R T, i}^{T} \cdot \hat{\beta}_{F E R T}+\sum_{m=1}^{M_{S}-1} \hat{\beta}_{m} \cdot S_{m, i}\right]\right) .
$$

The difference between the baseline share of $\mathrm{N}$ from agriculture and the $\mathrm{N}$ source share from agriculture evaluated at a policy mandate is $\Delta N_{F E R T, i}^{T}=\% N_{F E R T, i}^{T}-\% N_{F E R T, i}^{T=0}$, at $T=22,31,50$, and $100 \%$.

\subsection{Statistical Comparison of Baseline and Policy Outcomes}

Nitrogen runoff means of the policy scenarios are compared with the baseline runoff means using the two-sample non-parametric test of Kolmogorov and Smirnoff. The null hypothesis is that the distributions are not different. The null hypothesis that $\mathrm{N}$ runoff and the contribution of commercial agriculture's $\mathrm{N}$ to total runoff is tested as a binomial outcome focusing on positive and negative deviations from the baseline value.

\section{Results and Discussion}

3.1 Optimal Cellulosic Ethanol Refinery Location and Attendant Land Use Change 
Figure 2 highlights the union of the BioFLAME region coverage and the SAGT basin, with sited facilities and the corresponding land area impacted at each target level of production. The number of facilities and total quantity of cellulosic ethanol produced in the SAGT basin are lower than BioFLAME's projections for the Southeastern U.S. (Table 1) because BioFLAME's geographic coverage extends beyond the SAGT basin (Figure 1). Therefore, only 37\% (49 facilities $\times 283.88 \mathrm{mly} /$ facility) of the $100 \% 41.64$ bly target for the entire southeastern US could originate in the SAGT basin. This sub-region corresponds with the construction of 49 biorefineries and the conversion of 3.03 million hectares in hay, row crops, or pasture to switchgrass production.

Land use change projections for barley, corn, cotton, hay and pastureland, oats, sorghum, soybeans, and wheat converted to feedstock production at each policy target suggest that lands used for hay and pasture and oat production are converted earliest to switchgrass (Table 2). These changes are driven by the distribution of soils suitable for producing switchgrass, relatively lower transport costs, and the opportunity costs of typical land uses. Land used to produce crops of relatively higher value is not converted to switchgrass until higher levels of biofuel production are mandated.

When $22 \%$ of the cellulosic ethanol production mandate is achieved, 14 refineries produce 3.97 bly in the SAGT basin (Table 1). Approximately 0.73 million hectares of agricultural land are allocated to switchgrass production. The most intense facility location activity occurs in the Appalachian Plateau and Piedmont regions of southern and eastern Tennessee and the western Carolinas (Figure 2). Hay and pasture is converted first to feedstock production. Hay, pasture, and soybeans, all of which usually require less $\mathrm{N}$ than switchgrass, 
account for almost $95 \%$ of the converted area (Table 2). Soybeans typically receive little or no $\mathrm{N}$ fertilizer. When land allocated to soybeans is converted to switchgrass, these areas generate the greatest incremental increase in $\mathrm{N}$ use of the eight field crops considered. Soybean production is relatively low in $\mathrm{N}$ fertilizer application because soybeans fix nitrogen. Although soybean area constitutes only $20 \%$ of the total land converted at the $22 \%$ target, this area accounts for more than $80 \%$ of the net increase in total $\mathrm{N}$ applied in the basin.

When $31 \%$ of the mandate is achieved, 7.12 bly of cellulosic ethanol are produced in the SAGT basin by 25 refineries (Table 1). Correspondingly, 1.32 million hectares of agricultural land are converted to switchgrass production. At $31 \%$ of the mandate, conversion of hay and pastureland and oats to switchgrass production advances, with land in soybeans and wheat also converted to switchgrass production (Table 2). As with the $22 \%$ mandate, most of the converted area $(85 \%)$ is from hay and pasture land and soybeans, although soybeans represent a larger share of total land converted (33\%) than under the $22 \%$ mandate $(20 \%)$. The industry expands southward as biofuel production increases, and land used to produce higher valued crops is converted with increasing intensity. Terrain in this region is relatively flatter (as opposed to the distribution of forest land); hence the circular feedstock shed signatures surrounding these newly sited facilities (Figure 2).

Thirty-six refineries produce 10.22 bly in the SAGT basin when $50 \%$ of the mandate is achieved (Table 1). Facilities compete intensively as least cost sites are exhausted. Competition results in multiple facilities stacking on top of each other at single locations. Stacking suggests the presence of a single, large capacity plant; in this case with capacities of 851.63 mly. When $50 \%$ of the policy target is achieved, $95 \%$ of the acres originally in oat production are converted 
to energy feedstock production, and about two-thirds of the soybeans and barley acres are converted to switchgrass production (Table 2). The conversion of hay and pasture to switchgrass production continues, but at a relatively slow pace (3\% change from the $31 \%$ policy target). Soybean, hay and pasture land comprise 1.55 million hectares of the 2.13 million hectares converted (73\%), of which 0.81 million (38\%) are soybeans. Hay and pastureland account for 0.74 million (35\%) of total converted hectares, down from $52 \%$ under the $31 \%$ target. Wheat and cotton hectares account for $25 \%$ of the total area converted, up from $14 \%$ under the $31 \%$ target.

When $100 \%$ of the SAGT basin's share of the mandate is achieved, 49 refineries produce 13.93 bly of cellulosic ethanol with 3.03 million hectares of agricultural land converted to switchgrass production (Table 1). At the $100 \%$ target, $64 \%$ of the area originally in cotton production is used to produce switchgrass and more than $80 \%$ of the original wheat, soybean, and sorghum area is converted to switchgrass production. Only $2 \%$ of the original area in oats remain (Table 2). Corn area is least impacted (-12\% of the baseline area) because of the relatively high value of the crop. Soybeans and hay and pasture comprise 1.84 million hectares $(60 \%)$ of the total land converted, down from $73 \%$ under the $50 \%$ biofuel target.

\subsection{SPARROW Calibration and Baseline Estimates}

The regression model coefficient of determination was $R^{2}=0.97$ (Table 3). All of the source variables $\left(S_{m}\right)$ were strong predictors of $\mathrm{N}$ runoff throughout the system. The largest contributing factors to $\mathrm{N}$ runoff were sources originating from urban area impervious surfaces. Commercial fertilizer application is an important source determinant, but its relative contribution was less in magnitude compared to nitrogen mass from permitted wastewater discharge and 
ammonia and nitrate deposition. A 1-kilogram increase in commercial applied $\mathrm{N}$ was associated with a $0.11 \mathrm{~kg}$ increase in $\mathrm{N}$ runoff into the SAGT basin.

The calibrated model was used to generate baseline surfaces to analyze policy impacts. The predicted $\mathrm{N}$ runoff suggest high in-stream concentrations in the northwestern and southern reaches of the system (Figure 3). Commercially applied nitrogen accounts for a relatively greater share of the total predicted $\mathrm{N}$ runoff in an area extending from the southeastern portion of the basin upwards along the east coast.

The baseline upstream nitrogen yield was $4.17 \mathrm{~kg} \mathrm{ha}^{-1} \mathrm{yr}^{-1}$, most of which $(59.43 \%)$ originated from atmospheric $\mathrm{N}$ deposition (Table 4). The second largest contributing factor to $\mathrm{N}$ runoff was nitrogen applied by commercial agriculture (18.12\%), followed by nitrogen from manure sources $(10.87 \%)$ and runoff from impermeable surfaces $(8.04 \%)$. Of the $\mathrm{N}$ sources, waste water discharge contributed least to upstream nitrogen yield (3.52\%). The baseline estimates are within range of Hoos and McMahon's findings (2009) for the same region.

\subsection{Changes in N Source Shares under Cellulosic Biofuel Production Targets}

Other nitrogen source variables were held constant during the simulation (e.g., urban waste water discharge and atmospheric N). Only the amount of $\mathrm{N}$ applied in the commercial agriculture sector changed. It is not surprising the simulated means of these source variables, averaged across the 8,321 watersheds, are not statistically different from the baseline estimate (Table 4). Similarly, averaging across all watersheds, the net change in agriculture's share to N runoff $\left(\% N_{F E R T, i}^{T}\right)$ evaluated at each policy target is not different from the baseline level. In aggregate terms, the calibrated equilibrium appears to be maintained in each scenario relative to 
the baseline, but the spatial distribution of source shares differs from one level of production to another (Figure 4).

Comparisons of the difference between the baseline share of $\mathrm{N}$ from commercial agriculture and the nitrogen source shares estimated under each policy $\left(\Delta N_{F E R T, i}^{T}\right)$ suggests the impacts of an expanding cellulosic ethanol sector are spatially heterogeneous (Figure 4). Some watersheds experience a decrease in agriculture's share of contributions to $\mathrm{N}$ runoff while others experience an increase. These changes are driven by the attendant changes in fertilizer demand by crops. The changes in the share of nitrogen from agriculture contributing to total $\mathrm{N}$ runoff ranged from -65 to $+16 \%$ (for the $22 \%$ ethanol production target) and from -61 to $+29 \%$ at $100 \%$ production level.

The empirical distributions of the baseline-target differences $\left(\Delta N_{F E R T, i}^{T}\right)$ confirm these observations (Figure 5). On average, $\Delta N_{F E R T, i}^{T}$ is not different from zero. However, as Figures 3 and 5 suggest, variation around the mean increases as the ethanol production target increases and demand for energy feedstock grows.

Indicating watersheds experiencing a net decrease with 1 , and 0 otherwise, we apply Chebychev's inequality to evaluate the likelihood of observing net positive or negative changes from the baseline as a Bernoulli $(p)$ distribution (Casella and Berger, 1990). For example, when the $22 \%$ target is achieved, land is converted from conventional crop and pastureland uses to switchgrass production in 3,643 watersheds (Figure 2). Of these watersheds, relative to the baseline, the share of $\mathrm{N}$ runoff contributed by commercial fertilizer use decreased in 2,440 watersheds $(p=2,440 / 3,643=0.67)$. Assuming that the sign of the difference between the baseline and policy simulated value are equally likely among all watersheds under the null 
hypothesis, then the expected value of the sample proportion is $p=0.50$, with variance [( $1-$ $0.5) \cdot 0.5] / 3,643$, and a standard deviation of 0.0083 . In the case of commercial agriculture's share of $\mathrm{N}$ runoff under the $22 \%$ scenario, the value $p=0.67$ is 20.50 standard deviations away from the null value of 0.5 . From Chebychev's inequality, this outcome would occur with probability $(1 / 20.50)^{2}=0.0024$. In other words, a value as large as 2,440 watersheds exhibiting decreases in agriculture's contribution to total $\mathrm{N}$ runoff would occur about 1 in 50 times if there were no prior expectations about an increase or decrease in agriculture's contribution to $\mathrm{N}$ runoff (e.g., the null sample proportion of $p=0.5$ ) from this change. There is reasonable evidence to suggest that commercial agriculture's share of $\mathrm{N}$ runoff would decrease in a majority of watersheds in the impacted region following changes in land use associated with meeting $22 \%$ of the RFS2 goal. Similar conclusions follow analysis of the $31 \%, 50 \%$, and $100 \%$ policy targets (Table 5).

\subsection{Changes in N Runoff Measures under a Cellulosic Biofuel Production Mandate}

On average, upstream nitrogen yield and concentration under the policy targets were not different from the baseline results (Table 4). The summary statistics are confirmed by inspection of the empirical distributions of the differences between $\mathrm{N}$ runoff and concentration levels estimated $(\Delta y)$ at the policy targets and the baseline estimates (Figure 5). However, as industry demand for biomass feedstock increases, the variability in the difference between the baseline and policy target nitrogen runoff indicators increases.

The downstream impacts of changes in land use on nitrogen runoff vary depending on the feedstock demand corresponding with each cellulosic ethanol target (Figure 6). The maps of Figure 6 highlight the spatial variation in the changes in $\mathrm{N}$ loading under each policy target. The 
map polygons (the individual watersheds) report the standard deviation away from the mean of $\mathrm{N}$ loading corresponding with the population of polygons $(n=8,321)$. However, the ranking of policies in terms of aggregate of $\mathrm{N}$ loading uniformly progress as the policy targets increases in terms of changes in magnitude (Table 5). The maps are highlight variation across spatial units, but in aggregate this variation is smoothed out. This likely results because of the mass balance modeling assumption maintained by SPARROW. This "averaging out effect" is also apparent in the cumulative density functions of Figure 5.

At the $22 \%$ target, $\mathrm{N}$ runoff intensifies in the northwestern region of the system as crops requiring relatively less $\mathrm{N}$ are replaced by switchgrass. The relationship is different in the eastern portion of the feedstock shed. Holding settlement patterns, geological features, and other sources of $\mathrm{N}$ constant, nitrogen runoff decreases where crops requiring relatively large amounts of nitrogen are replaced by switchgrass.

As competition for low-costs sites increases so too does the intensity of land converted to the production of biomass feedstock. Positive downstream externalities, in terms of reductions in $\mathrm{N}$ loading outside the feedstock shed, are evident in the southern reach of SAGT basin as switchgrass production expands southward. These off-site benefits are generated by the conversion of relatively $\mathrm{N}$-intensive crops by switchgrass. At $31 \%$ of the mandate, the initial increase in $\mathrm{N}$ runoff observed in the northeastern portion of the basin decreases relative to the baseline as $\mathrm{N}$-intensive crops produced in the region are replaced with switchgrass.

In the aggregate, total reduction in $\mathrm{N}$ runoff ranges from $-2,581 \mathrm{~kg} \mathrm{ha}^{-1} \mathrm{yr}^{-1}(000 \mathrm{~s})$ at the $22 \%$ target to $-7,320(000$ s) at the $100 \%$ target (Table 5). At the $22 \%$ threshold, $64 \%$ of the watersheds that undergo conversion of agricultural land to switchgrass production experience a 
reduction in nitrogen runoff. The area-wide reduction in $\mathrm{N}$ runoff decreases as higher policy targets are reached. When $100 \%$ of the production goal is achieved, only $41 \%$ of the impacted watersheds register a reduction in $\mathrm{N}$ runoff. This occurs because switchgrass production intensifies on land not usually receiving as much nitrogen as required by switchgrass, increasing the relative amount of nitrogen used by the commercial agriculture sector. The number of watersheds exhibiting a reduction in nitrogen runoff following the intervention is not likely due to chance, as evidenced by the probabilities estimated using Chebychev's inequality (Table 5).

\section{Conclusion}

This study examined the ex-ante impacts of the Renewable Fuel Standard's cellulosic biofuel mandate on water quality in the southeastern United States. The analysis focuses on switchgrass as a feedstock for bioethanol, and provides a picture of the spatial distribution and aggregate impacts of expected changes on nutrient loading into the Southeastern-Atlantic, Eastern Gulf, and Tennessee River basin. The expansion of cellulosic bioenergy feedstock production in this region could significantly impact water quality due to attendant changes in land use. Yet, the water quality benefits associated with conversion to switchgrass may be overstated because the lands most likely to be converted are those that are also low in fertilizer applications. Under most cellulosic ethanol production levels, the average basin-wide changes in indicator levels are statistically insignificant. Examination of the changes at finer spatial scales suggests moderate spatial heterogeneity in expected changes in watersheds in terms of both overall $\mathrm{N}$ runoff into the SAGT basin and agriculture's contribution to total N runoff. Local impacts will vary depending on baseline cropping patterns, commodity prices, transport costs, and the intensity of conversion 
of row crops and pastureland into switchgrass production. Areas with high concentrations of cereals, soybean production, and hay and pasture appear to experience significant changes in $\mathrm{N}$ loading from agriculture relative to areas where other agricultural enterprises are more prevalent. Findings of this study may complement ongoing efforts to maintain and restore impaired water bodies, as well as preserve the status of historically healthy water bodies, with targeted nutrient management efforts including vegetative buffer strips, wetland construction, and precision fertilizer application.

There are important limitations and caveats to this research. First, intensification of traditional crop production was not factored into this analysis. For this study, it was assumed that there would be no expansion of traditional crop production coincident to the conversion of agricultural land to switchgrass production. Indirect land use change or intensification of crop production from baseline levels could significantly impact water quality in the study region and elsewhere. Second, it is difficult to model nitrogen fixation by soybeans in the SPARROW system. This shortcoming could potentially result in underestimating changes in $\mathrm{N}$ loadings associated with conversion of soybean area to switchgrass production. Third, the assumptions that pasture and land cultivated in hay receive the same quantity of $\mathrm{N}$ may be untenable. The 2009 USDA Census of Agriculture did not distinguish between land in hay and pastureland. This limitation precluded calculating the quantity of $\mathrm{N}$ applied to each land use separately. Therefore, the relative contributions of hay and pastureland to runoff represent an upper-bound estimate since less $\mathrm{N}$ is usually applied on pasture. Finally, the counterfactual scenario depends critically on the assumption that fertilizer $\mathrm{N}$ expenditures were similar between 2002 and 2009. It was not 
until 2009 that NASS produced high-resolution cropland data layers for the southeastern region for public use, which precluded generating a comparable data surface for 2002.

With these caveats in mind, this research advances the empirical methodology of integrating economic models that determine optimal industry configurations and concomitant land use change with mass-balance hydrologic models. The integration of both systems bridges economic policy impact analysis with natural biophysical processes. The methodology developed allows for examination of proportional changes in indicators comparing pre- and postpolicy environments, ceteris paribus. The present modeling endeavor offers insight into the extent of potential impacts to water quality associated with RFS2-type cellulosic ethanol production mandates. Other well-established water quality models, including the Soil and Water Assessment Tool or the US Department of Energy's enhanced version of SWAT, the Biomass Location for Optimal Sustainability Model (BLOSM) (Parish et al., 2012) could be candidates to extend the simulation procedure suggested in this research. 


\section{Acknowledgements}

This project was supported by Agriculture and Food Research Initiative Competitive Grant no.

11025775 from the USDA National Institute of Food and Agriculture. The views expressed here are those of the co-authors. The authors are grateful to Dr. Anne Hoos, United States Geological Survey (USGS) Nashville, TN, for technical support and expertise with SPARROW. 


\section{References}

Alexander, R.B., Smith, R.A., Schwarz, G.E., 2000. Effect of Stream Channel Size on the Delivery of Nitrogen to the Gulf of Mexico. Nature 403:758-761.

American Society of Agricultural Engineers (ASAE), 2009. Agricultural Machinery Management, ASAE Standard EP496.3, ASAE, St Joseph, MI.

Ator, S.W., J.W. Brakebill, and J.D. Blomquist. Sources, Fate, and Transport of Nitrogen and Phosphorus in the Chesapeake Bay Watershed: An Empirical Model. United States Geological Survey Scientific Investigations Report 2011-5167, 38 p.

Brechbill, S.C., Tyner, W.E., Ileleji, K.E., 2008. The Economics of Biomass Collection and Transportation and its Supply to Indiana Cellulosic and Electric Utility Facilities, Proceedings of the Risk, Infrastructure and Industry Evolution Conference, Berkeley, CA, June 24-25, Farm Foundation, Oak Brook, IL, pp. 105-15. www.farmfoundation.org/news/articlefiles/365-Berkeley\%20proceedings.pdf

Blackhurst, M., C. Hendrickson, and J. Sels I Vidal. 2010. Direct and Indirect Water

Withdrawals for U.S. Industrial Sectors. Environment, Science, and Technology 44: 2126-2130.

Cassella, G. and Berger, R. L. 1990. Statistical Inference. Belmont, California: Duxbury Press.

Costello, C., Griffin,W.M., Landis, A.E., Matthews, H.S., 2009. Impact of Biofuel Crop Production on the Formation of Hypoxia in the Gulf of Mexico. Environmental Science and Technology. 43:7985-7991.

De La Torre Ugarte, D.G., Ray, D.E., Dicks, M.R., Tiller, K.H., 1997. The POLYSYS Modeling Framework: A Documentation. http://www.agpolicy.org/tools/doccom.pdf.

De La Torre Ugarte, D.G., English, B.C., Jensen, K., 2007. Sixty Billion Gallons by 2030: Economic and Agricultural Impacts of Ethanol and Biodiesel Expansion. American J. of Agricultural Economics. 89:1290-1295.

de Koff, J. P., Tyler, D.D., 2011. Improving Switchgrass Yields for Bioenergy Production. W271 University of Tennessee Extension and ANR-B1 Tennessee State University. https://utextension.tennessee.edu/publications/Documents/W271.pdf

Demissie, Y., Yan, E., Wu, M., 2012. Assessing Regional Hydrology and Water Quality Implications of Large-Scale Biofuel Feedstock Production in the Upper Mississippi River Basin. Environmental Science and Technology. 46:9174-9182.

Donner, S.D., Kucharik, C.J., Foley, J., 2004. Impact of Changing Land Use Practices on Nitrate Export by the Mississippi River. Global Biogeochemical Cycles. 18:1-21. 
English, B., Yu, T.-H. E. Yu, Larson, J. Larson, Menard, J., Gao, Y. 2013. Economic Impacts of using Switchgrass as a Feedstock for Ethanol Production: A Case Study Located in East Tennessee. Economics Research International 2013: 1-14.

ESRI, 2005. Environmental Systems Research Institute. ESRI Data and Maps. Available at: http://www.esri.com/data/data-maps.

Hoos, A.B., Terziotti, S.E., McMahon, G., Savvas, K., Tighe, K.C., Alkons-Wolinsky, R., 2008. Data to Support Statistical Modeling of Instream Nutrient Load Based on Watershed Attributes, Southeastern United States, 2002. 2008 US Geological Survey Open-File Report 2008-1163, 50 pp.

Hoos, A.B., McMahon, G., 2009. Spatial Analysis of Instream Nitrogen Loads and Factors Controlling Nitrogen Delivery to Streams in the Southeastern United States Using Spatially Referenced Regression on Watershed Attributes (SPARROW) and Regional Classification Frameworks. Hydrologic Processes. 23 (16): 2275-2294.

Humbird, D., Davis, R., Tao, L., Kinchin, C., Hsu, D., Aden, A., Schoen, P., Lukas, J., Olthof, M., Worley, M., Sexton, D., Dudgeon, D., 2011. Process Design and Economics for Biochemical Conversion of Lignocellulosic Biomass to Ethanol. Technical Report NREL/TP-5100-47764, Contract No. DE-AC36-08GO28308.

Jensen, K.L., Clark, C.D., Ellis, P., English, B., Menard, J., Walsh, M., de la Torre Ugarte, D., 2007. Farmer Willingness to Grow Switchgrass for Energy Production, Biomass and Bioenergy 31(11-12): 773-81.

Khanna, M, X Chen, H Huang, H Önal. 2011a. Supply of Cellulosic Biofuel Feedstocks and Regional Production Pattern. American Journal of Agricultural Economics 93(2):473-480.

Khanna, M, A Jain, A Oliver. 2011b. Production of Bioenergy Crops in the Midwest. Farm Economics, April 1, 2011, Available at: http://www.farmdoc.illinois.edu/manage/newsletters/fefo11_06/fefo11_06.html (accessed 3/17/2016).

Lambert, D.M., Wilcox, M.D., English A., Stewart, L. 2008. Ethanol Plant Location Determinants and County Comparative Advantage. Journal of Agriculture and Applied Economics, 40(1):117-135.

Lambert, D.M., McNamara, K.T. 2009. Location Determinants of Food Manufacturers in the U.S., 2000 - 2004: Are Nonmetropolitan Counties Competitive? Agricultural Economics, 40(6):617-630, doi: 10.1111/j.1574-0862.2009.00403.x. 
Lambert, D.M., Wilson, B., Menard, R.J., Jensen, K.L., English, B.C., 2014. Optimal Location of Cellulosic Biofuel Facilities and their Impact on Employment in the Southeast Region. In in the Proceedings of the Association for the Advancement of Industrial Crops-Agriculture and Food Research Initiative (AAIC-AFRI) Conference, "New Crops, Bioenergy, Biomaterials, and Sustainability", Washington, D.C., October 13-16, 2013, https://hort.purdue.edu/newcrop/proceedings2015/399-lambert.pdf.

Larson, J.A., English, B.C., Hellwinckel, C., De La Torre Ugarte, D., Walsh, M., 2005. A farmlevel Evaluation of Conditions under Which Farmers Will Supply Biomass Feedstocks for Energy Production. Selected Paper at the 2005 American Agricultural Economics Association Annual Meeting, 24-27 Jul. 2005, Providence, RI.

McCann, P., 2013. Modern Urban and Regional Economics. Oxford University Press.

McIsaac, G.F., David, M.B., Mitchell, C.A., 2010. Miscanthus and Switchgrass Production in Central Illinois: Impacts on Hydrology and Inorganic Nitrogen Leaching. Journal of Environmental Quality 39(5): 1790-1799.

McKinley, T.L., Gerloff, D.C., 2010. Field Crops Budgets for 2010, Department of Agricultural and Resource Economics AE10-06, University of Tennessee, Knoxville, TN. Available at: http://economics.ag.utk.edu/budgets.html.

Moore, R.B., C.M. Johnson, R.A. Smith, and B. Milstead. 2011. Source and Delivery of Nutrients to Receiving Waters in the Northeastern and Mid-Atlantic Regions of the United States. Journal of the American Water Resources Association 47(5): 965-990.

NASS, 2008. National Agricultural Statistics Service. Data and Statistics. Available at: http://www.nass.usda.gov/Data_and_Statistics/index.asp.

National Research Council, 2011. Renewable Fuel Standard: Potential Economic and Environmental Effects of US Biofuel Policy. Washington, DC: The National Academies Press.

Parish E, Hilliard, M, LM Baskaran, VH Dale, NA Griffiths, PJ Mulholland, A Sorokine, ME Downing, R Middleton, NA Thomas. 2012. Multimetric Spatial Optimization of Switchgrass Plantings Across a Watershed. Biofuels, Bioproducts, and Biorefineries 6: 58-72.

Perlack, R. D., Stokes, B. J., 2011. U.S. Billion-Ton update: Biomass Supply for a Bioenergy and Bioproducts Industry. Oak Ridge National Laboratory: Oak Ridge, TN: U.S. Department of Energy.

Qian, S.S., Reckhow, K.H., Zhai, J., McMahon, G., 2005. Nonlinear Regression Modeling of Nutrient Loads in Streams: a Bayesian Approach. Water Resources Res. 41, W07012, doi:10.1029/2005WR003986. 
Robertson, G.P., Hamilton, S.K., Del Grosso, S.J., Parton, W.J., 2010. The Biogeochemistry of Bioenergy Landscapes: Carbon, N, and Water Considerations. Ecological Applications. 21:1055-1067.

Ruddy, B.C., Lorenz, D.L., Mueller, D.K., 2006. County-Level Estimates of Nutrient Inputs to the Land Surface of the Conterminous United States, 1982-2001:

U.S. Geological Survey Scientific Investigations Report 2006-5012, 17 p.

Schnepf, R., Yacobucci, B.D., 2013. Renewable Fuel Standard (RFS): Overview and Issues. Congressional Research Service. http://fas.org/sgp/crs/misc/R40155.pdf

Schwarz, G.E., Hoos, A.B., Alexander, R.B., Smith, R.A., 2006. The SPARROW Surface Water Quality Model-Theory, Applications and User Documentation: U.S. Geological Survey,

Techniques and Methods Book 6, Section B, Chapter 3, U.S. Geologic Survey, Reston, Virginia. http://pubs.usgs.gov/tm/2006/tm6b3/PDF.htm.

Seaber, P.R., Kapinos, F.P., Knapp, G.L., 1987. Hydrologic Unit Maps. U.S. Geological Survey Water-Supply Paper 2294, 63 pp.

Shapouri, H., Gallagher, P., 2005. USDA's 2002 Ethanol Cost-of-Production Survey. ESCS for. Agricultural Economics Report 841. Washington, D.C.: U.S. Department of Agriculture. Seaber, P.R., Kapinos, F.P., and Knapp, G.L., 1987, Hydrologic Unit Maps: U.S. Geological Survey Water-Supply Paper 2294, 63 p

Smith, C.M., David, M.B., Mitchell, C.A., Masters, M.D., Anderson-Teixeira, K.J., Bernacchi, C.J., DeLucia, E.H., 2013. Reduced Nitrogen Losses after Conversion of Row Crop Agriculture to Perennial Biofuel Crops. Journal of Environmental Quality 42: 219-228.

Smith, R.A., Schwarz, G.E., Alexander, R.B., 1997. Regional Interpretation of Water-Quality Monitoring Data. Water Resources Res. 33(12):2781-2798.

SSURGO, 2009. Soil Survey Staff, Natural Resource Conservation Service, USDA. Soil Survey Geographic (SSURGO) Database. Available at: http://websoilsurvey.nrcs.usda.gov/.

U.S. Congress, 2005. Energy Policy Act of 2005. Washington, DC: Public Law 109-58, $109^{\text {th }}$ Cong., $1^{\text {st }}$ sess., August 8, Title XV, Sec. 1501. http://www.epa.gov/oust/fedlaws/publ_109058.pdf.

U.S. Congress, 2007. Energy Independence and Security Act of 2007. Washington, DC: Public Law 110-140, 110th Cong., 1st sess., December 19, Title II, Sec. 202. http://frwebgate.access .gpo.gov/cgi-bin/getdoc.cgi?dbname=110_cong_public_laws\&docid =f:publ140.110. 
USDA, 2009. Economics, Statistics, and Market Information System. Field and Miscellaneous Crop Price Per Unit. U.S. Department of Agriculture, Washington, D.C. Available at: http://usda.mannlib.cornell.edu/.

USDA, 2010. A Regional Roadmap to Meeting the Biofuels Goals of the Renewable Fuel Standard by 2022, USDA Biofuels Strategic Production Report. U.S. Department of Agriculture, Washington, D.C. http://www.usda.gov/ documents/USDA_Biofuels_Report_6232010.pdf.

USDA, 2011a. Farm Services Agency. Biomass Crop Assistance Program (BCAP) Fact Sheet U.S. Department of Agriculture, Washington, D.C.

https://www.fsa.usda.gov/Internet/FSA_File/bcap_update_may2011.pdf.

USDA, 2011b. Quick Stats. National Agricultural Statistics Service. U.S. Department of Agriculture, Washington, D.C. Available at: http://quickstats. nass.usda.gov/.

United States Department of Agriculture/National Agricultural Statistics Service, 2013. Quick Stats, http://quickstats.nass.usda.gov/results/1B787CCA-DA39-372B-BD5E-DBDBF748A430 (accessed 9/23/2014).

U.S. EPA, 2013. EPA Proposes 2014 Renewable Fuel Standards, 2015 Biomass-Based Diesel Volume. U.S. Environmental Protection Agency, Washington, D.C. http://www.epa.gov/otaq/fuels/renewablefuels/documents/420f13048.pdf

Wilson, B. 2009. Modelling cellulosic ethanol plant location using GIS. MS Thesis, University of Tennessee, Knoxville.

Wilson, B, D de la Torre Ugarte, BC English. 2011. Modeling Biorefinery location using GIS. Final Report submitted to the Southeastern Sun Grant Center, Dept. of Agricultural \& Resource Economics, University of Tennessee, Knoxville.

Wright, L.L. and Turhollow, A.F. 2010. Switchgrass Selection as A "Model” Bioenergy Crop: A History Of The Process. Biomass and Bioenergy (2010), doi:10.1016/j.biombioe.2010.01.030

Wu, M., Chiu, Y., Demissie, Y. 2012. Quantifying the Regional Water Footprint of Biofuel Production by Incorporating Hydrologic Modeling. Water Resources Res. (48) 1-11. 
Table 1. Number of cellulosic ethanol refineries, production volume, and switchgrass feedstock demand in the Southeastern-Atlantic, Eastern Gulf, and Tennessee River (SAGT) basin and southeastern United States at 22\%, 31\%, 50\%, and 100\% of the 41.64 bly cellulosic ethanol target

\begin{tabular}{lcccc}
\hline & $\begin{array}{c}\text { Percent of } \\
\text { policy target }\end{array}$ & $\begin{array}{c}\text { Cellulosic ethanol } \\
\text { refineries (number)* }\end{array}$ & $\begin{array}{c}\text { Volume } \\
\text { (bly)** }\end{array}$ & $\begin{array}{c}\text { Feedstock } \\
\text { demand } \\
\text { (millions of ha) }\end{array}$ \\
\hline Southeast Region & $22 \%$ & 32 & 9.08 & 1.52 \\
& $31 \%$ & 45 & 12.79 & 2.18 \\
& $50 \%$ & 74 & 21.00 & 3.61 \\
\hline SAGT Region & $100 \%$ & 147 & 41.75 & 7.20 \\
\hline $31 \%$ & 14 & 3.97 & 0.73 \\
& $50 \%$ & 36 & 7.12 & 1.32 \\
& $100 \%$ & 49 & 10.22 & 2.12 \\
& & & 13.93 & 3.03 \\
\hline
\end{tabular}

Notes: *, switchgrass feedstock; **, billion liters per year. 
Table 2. Aggregate area and nitrogen applied under baseline and policy simulations

Production area:

$\underline{\text { Crop }}$

Barley

Corn

Cotton

Hay/Pastureland

Oats

Sorghum

Soybeans

Wheat

Switchgrass

Applied Nitrogen:

$\underline{\text { Crop }}$

Barley

Corn

Cotton

Hay/Pastureland

Oats

Sorghum

Soybeans

Wheat

Switchgrass

Total $\mathrm{N}$ applied

(000's kg)

Field crops*

All other crops

All agriculture $\underline{\text { Base (000's ha) }}$

5.41

772.08

$1,176.78$

$1,969.98$

15.18

4.80

$1,213.98$

372.44

0

Percent of target achieved:

\begin{tabular}{|c|c|c|c|}
\hline $22 \%$ & $\underline{31 \%}$ & $\underline{50 \%}$ & $100 \%$ \\
\hline & & & \\
\hline$-13 \%$ & $-13 \%$ & $-66 \%$ & $-71 \%$ \\
\hline $0 \%$ & $0 \%$ & $-1 \%$ & $-12 \%$ \\
\hline$-1 \%$ & $-7 \%$ & $-22 \%$ & $-64 \%$ \\
\hline$-28 \%$ & $-35 \%$ & $-38 \%$ & $-39 \%$ \\
\hline$-30 \%$ & $-70 \%$ & $-95 \%$ & $-98 \%$ \\
\hline$-10 \%$ & $-15 \%$ & $-41 \%$ & $-83 \%$ \\
\hline$-12 \%$ & $-36 \%$ & $-67 \%$ & $-88 \%$ \\
\hline$-8 \%$ & $-29 \%$ & $-76 \%$ & $-91 \%$ \\
\hline
\end{tabular}

744

1,328

2,131

3,043

Percent of target achieved:

\begin{tabular}{|c|c|c|c|}
\hline $22 \%$ & $\underline{31 \%}$ & $\underline{50 \%}$ & $100 \%$ \\
\hline $240 \%$ & $31 \%$ & $760 \%$ & $-80 \%$ \\
\hline 140 & $21 \%$ & $28 \%$ & $-36 \%$ \\
\hline$-14 \%$ & $-26 \%$ & $\begin{array}{l}-20 \% \\
-44 \%\end{array}$ & $-75 \%$ \\
\hline$-34 \%$ & $-46 \%$ & $-54 \%$ & $-56 \%$ \\
\hline$-42 \%$ & $-76 \%$ & $-97 \%$ & $-99 \%$ \\
\hline$-21 \%$ & $-32 \%$ & $-60 \%$ & $-90 \%$ \\
\hline$-25 \%$ & $-53 \%$ & $-76 \%$ & $-86 \%$ \\
\hline$-20 \%$ & $-44 \%$ & $-82 \%$ & $-94 \%$ \\
\hline
\end{tabular}

46,941

77,803

113,746

161,425
0

95,851

39,091

568

6,213

30,733
282,345

402,262

684,607

279,626
402,262
681,888

$\begin{array}{lll}276,309 & 270,348 & 275,694 \\ 402,262 & 402,262 & 402,262 \\ 678,571 & 672,610 & 677,956\end{array}$

Notes: *field crops include barley, corn, wheat, soybeans, cotton, sorghum, oats, switchgrass, and hay and pastureland. 
Table 3. Spatially Referenced Regression on Watershed Attributes (SPARROW) regression

\begin{tabular}{lccc}
\hline Variables & Units & Coefficient & Std. error \\
\hline Dependent variable - Nitrogen loading $(\mathrm{kg})$ & & & \\
Source input variables $\left(S_{m}\right)$ : & & & \\
$\quad$ Nitrogen mass in permitted wastewater discharge, 2002 & $\mathrm{~kg} / \mathrm{kg}$ & 0.7903 & $0.1039^{* * *}$ \\
$\quad$ Wet deposition of nitrogen (ammonia and Nitrate), detrended to 2002 & $\mathrm{~kg} / \mathrm{kg}$ & 0.4940 & $0.0423^{* * *}$ \\
Area of impervious surfaces, 2001 & $\mathrm{kg} / \mathrm{km}{ }^{2}$ & 2477.62 & $430.56^{* * *}$ \\
Nitrogen mass in commercial fertilizer applied to agricultural land, 2002; & $\mathrm{kg} / \mathrm{kg}$ & 0.1063 & $0.0173^{* * *}$ \\
Nitrogen mass in manure from livestock production, 2002 & $\mathrm{kg} / \mathrm{kg}$ & 0.0522 & $0.0112^{* * *}$ \\
Physical landscape variables $\left(Z^{D}\right):$ & & & \\
Ln of soil permeability, low value & $\mathrm{cm} / \mathrm{day}$ & & \\
Ln of depth to bedrock & $\mathrm{cm}$ & -0.2829 & $0.1533^{*}$ \\
Ln of mean annual precipitation & $\mathrm{mm}$ & 1.1635 & $0.2593^{* * *}$ \\
Fraction of catchment in HLR2; & percent & -0.2239 & $0.0953^{* *}$ \\
Fraction in HLR 4 & percent & 0.2906 & $0.1035^{* * *}$ \\
Fraction in HLRs 6, 9, or 11 & percent & 0.2874 & $0.0948^{* * *}$ \\
\hline
\end{tabular}

estimates for the study region 


\begin{tabular}{lccc}
\hline Fraction in HLR 7 & percent & -0.2645 & $0.1056^{* *}$ \\
Fraction in HLR 16 & percent & -0.1258 & 0.1108 \\
Stream variables $\left(Z^{S}\right)$ : & percent & & \\
Time of travel in reach segments where mean $\mathrm{Q}<2.8 \mathrm{~m}^{3} / \mathrm{s} / \mathrm{day}$ & $\mathrm{m}^{3} / \mathrm{s} / \mathrm{day}$ & 0.1397 & $0.0420^{* * *}$ \\
Time of travel in reach segments where mean $\mathrm{Q}>2.8$ and $<28 \mathrm{~m}^{3} / \mathrm{s} /$ day & $\mathrm{m}^{3} / \mathrm{s} / \mathrm{day}$ & 0.1934 & 0.0308 \\
Reservoir variable $\left(Z^{R}\right)$ : & & & \\
$\quad$ Inverse of areal hydraulic loading & $\mathrm{m} / \mathrm{yr}$ & 10.5081 & $3.2576^{* * *}$ \\
& & & \\
Adjusted $R^{2}$ & & 0.9657 \\
$n$ & & 321 & \\
\hline
\end{tabular}

Notes: HLR, hydrologic landscape region, described in Wolock and others (2004); kg, kilogram; $\mathrm{km}^{2}$, square kilometer, cm, centimeter; mm, millimeter; s, second; yr, year; Ln, natural logarithm transformation, ${ }^{1} \mathrm{~kg} \mathrm{ha}^{-1} \mathrm{yr}^{-1},{ }^{2} \%$ of $\mathrm{CA},{ }^{* * *}, * *, *$, significant at the $1 \%, 5 \%$, and $10 \%$ levels, respectively. All source variable variance inflation factors $<10$. 
Table 4. Nitrogen loading yield and source shares means for the Southeastern-Atlantic, Eastern Gulf, and Tennessee River (SAGT) basin; baseline and post-policy simulations

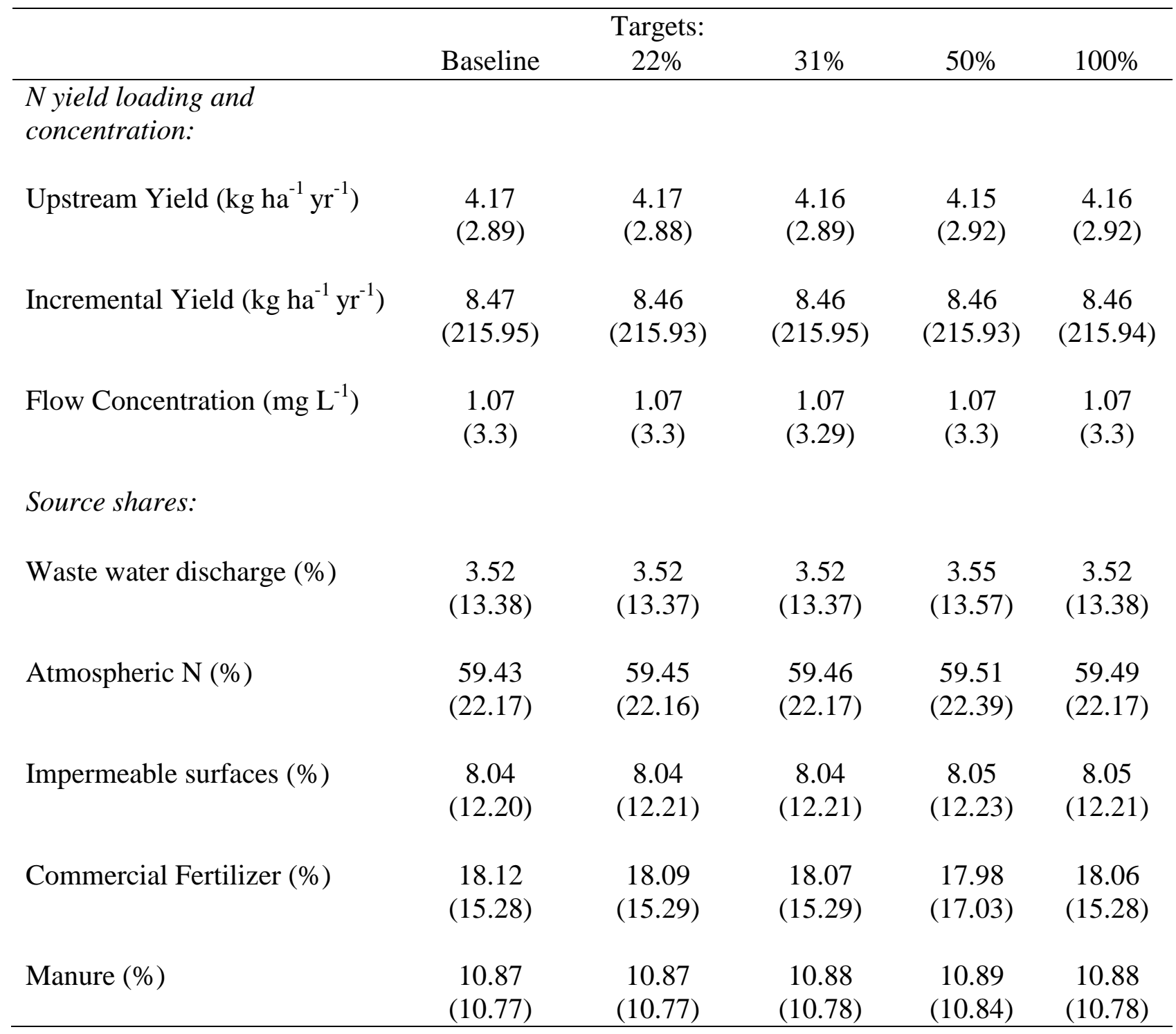

Notes: $N=8,321$ watersheds. Standard deviations of the means are in parentheses. Target values are not significantly different from the baseline estimates $(\mathrm{P}>0.05$, Kolmogorov-Smirnoff twosample test of equality between distributions). 
Table 5. Difference analysis for nitrogen loading and commercial agriculture's share to N loading in the Southeastern-Atlantic, Eastern Gulf, and Tennessee River (SAGT) basin

\begin{tabular}{|c|c|c|c|c|}
\hline Policy: & $22 \%$ & $31 \%$ & $50 \%$ & $100 \%$ \\
\hline & \multicolumn{4}{|c|}{--------N source: change from baseline (\%)----- } \\
\hline$n$ & 3643 & 5273 & 5856 & 6090 \\
\hline Mean & -0.059 & -0.075 & -0.074 & -0.097 \\
\hline Standard deviation & 1.364 & 1.507 & 1.496 & 1.797 \\
\hline Minimum & -64.715 & -74.330 & -67.504 & -60.988 \\
\hline Maximum & 16.375 & 16.373 & 19.036 & 29.253 \\
\hline Target < baseline: watershed count: & 2440 & 3404 & 3640 & 3915 \\
\hline Sample proportion: $\operatorname{target}<$ baseline: & 0.67 & 0.65 & 0.62 & 0.64 \\
\hline Standard deviation from expected mean: & 20.495 & 21.139 & 18.608 & 22.297 \\
\hline \multirow[t]{2}{*}{ Probability $1 /$} & 0.0024 & 0.0022 & 0.0029 & 0.0020 \\
\hline & \multicolumn{4}{|c|}{--N runoff: change from baseline $\left(\mathrm{kg} \mathrm{ha}^{-1} \mathrm{yr}^{-1}\right)--$} \\
\hline$n$ & 3643 & 5273 & 5856 & 6090 \\
\hline Mean & -305 & -1508 & -1857 & -1789 \\
\hline Standard deviation & 7426 & 12085 & 14749 & 15860 \\
\hline Minimum & -121150 & -183225 & -257872 & -251516 \\
\hline Maximum & 15855 & 12425 & 12429 & 569981 \\
\hline Target < baseline: watershed count: & 2342 & 3339 & 3828 & 4013 \\
\hline Sample proportion: $\operatorname{target}<$ baseline: & 0.64 & 0.63 & 0.65 & 0.66 \\
\hline Standard deviation from expected mean: & 17.25 & 19.35 & 23.52 & 24.81 \\
\hline Probability: $1 /$ & 0.0034 & 0.0027 & 0.0018 & 0.0016 \\
\hline $\begin{array}{l}\text { Percent of all watersheds with reduction in } \mathrm{N} \\
\text { loading: }\end{array}$ & $64 \%$ & $47 \%$ & $43 \%$ & $41 \%$ \\
\hline $\begin{array}{l}\text { Aggregate reduction in } \mathrm{N} \text { loading } \\
\left(000 \mathrm{sg} \mathrm{ha}^{-1} \mathrm{yr}^{-1}\right) \text { : }\end{array}$ & -2581 & -5597 & -6968 & -7320 \\
\hline
\end{tabular}

Notes: 1/ Probability calculated according to Chebychev's inequality; $\operatorname{Pr}[|X-\mu|>k \cdot \sigma] \leq 1 / k^{2}$ for any $k>1$ which measures the standard deviations of $X$ from a central tendency, $\mu$ (Casella and Berger, 1990). 

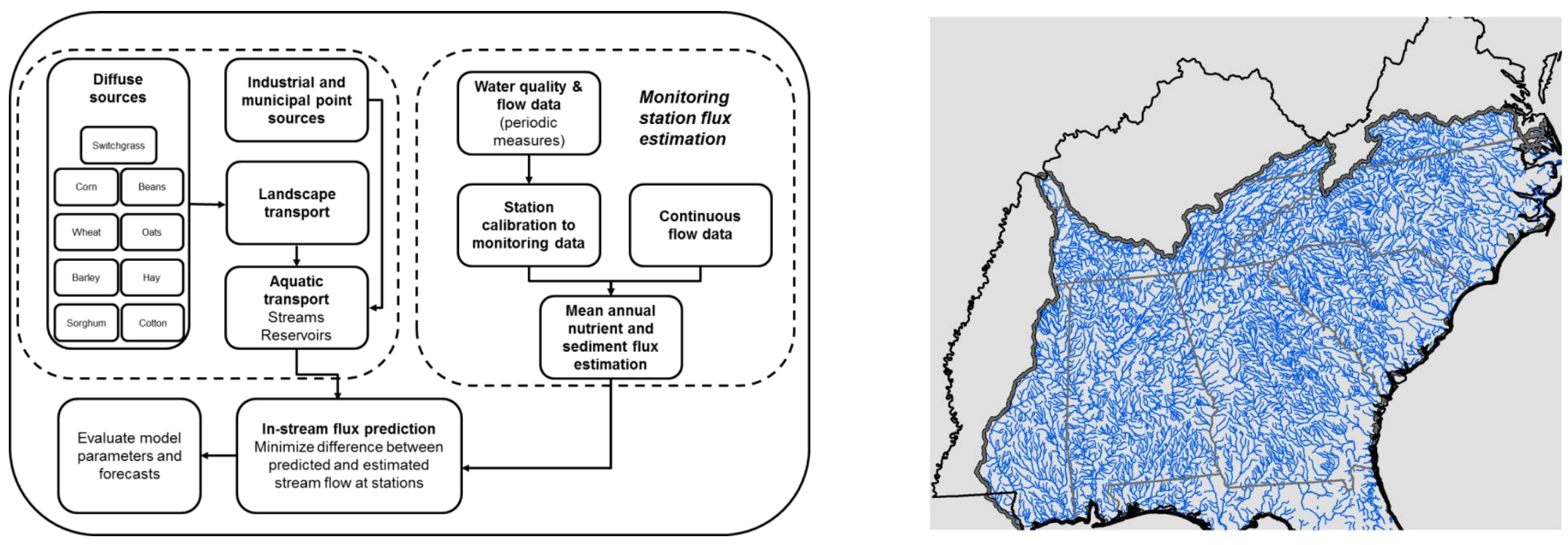

Figure 1. Spatially Referenced Regressions on Watershed Attributes (SPARROW) model structure (modified from Schwarz et al. 2006) and the Southeastern-Atlantic, Eastern Gulf, and Tennessee River (SAGT) hydrologic basin 

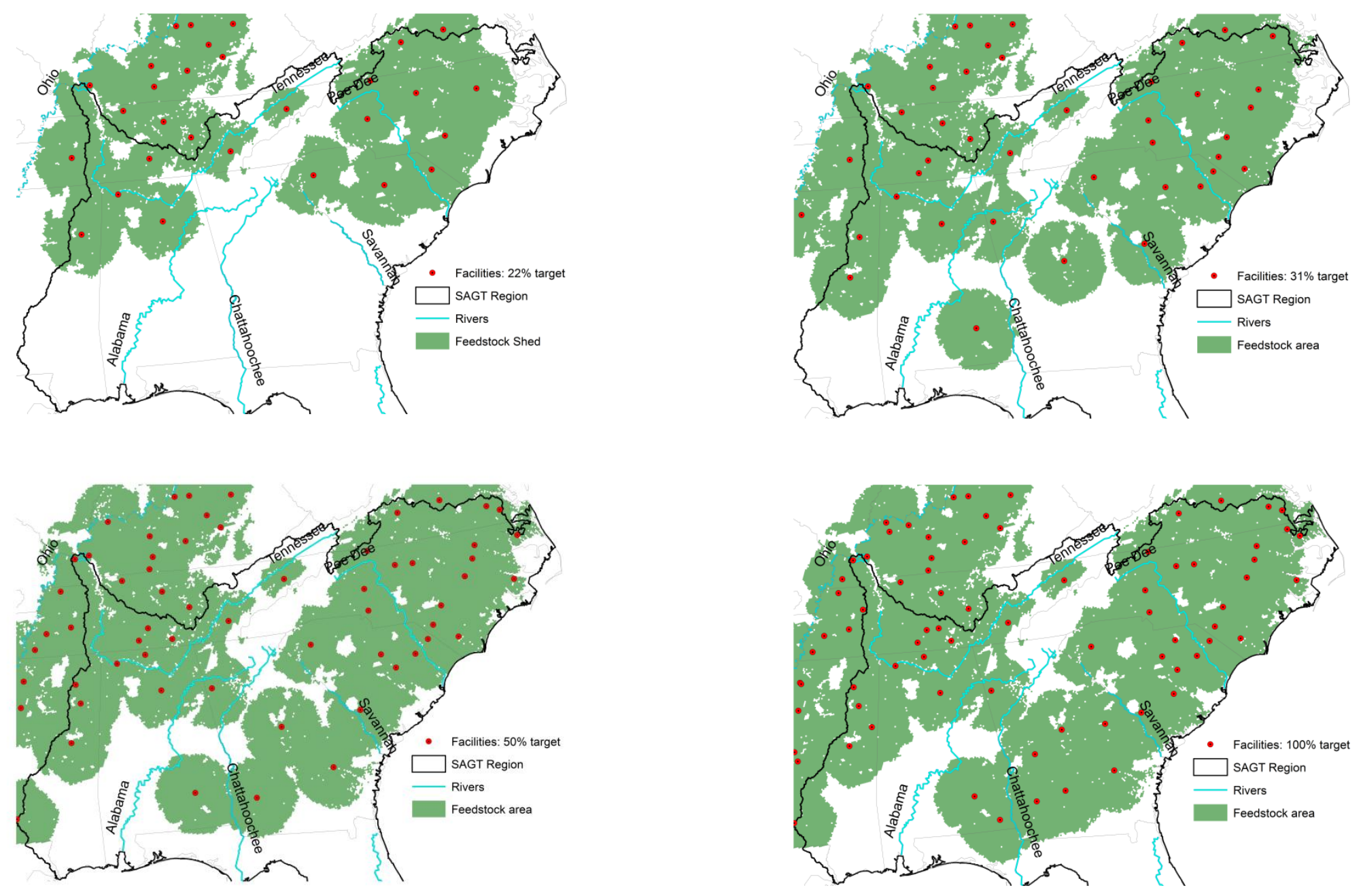

Figure 2. Distribution of optimal facility locations, feedstock sheds, and the Southern Atlantic-Gulf-Tennessee (SAGT) basin. 
a) Calibrated baseline, $\mathbf{N}$ Loading

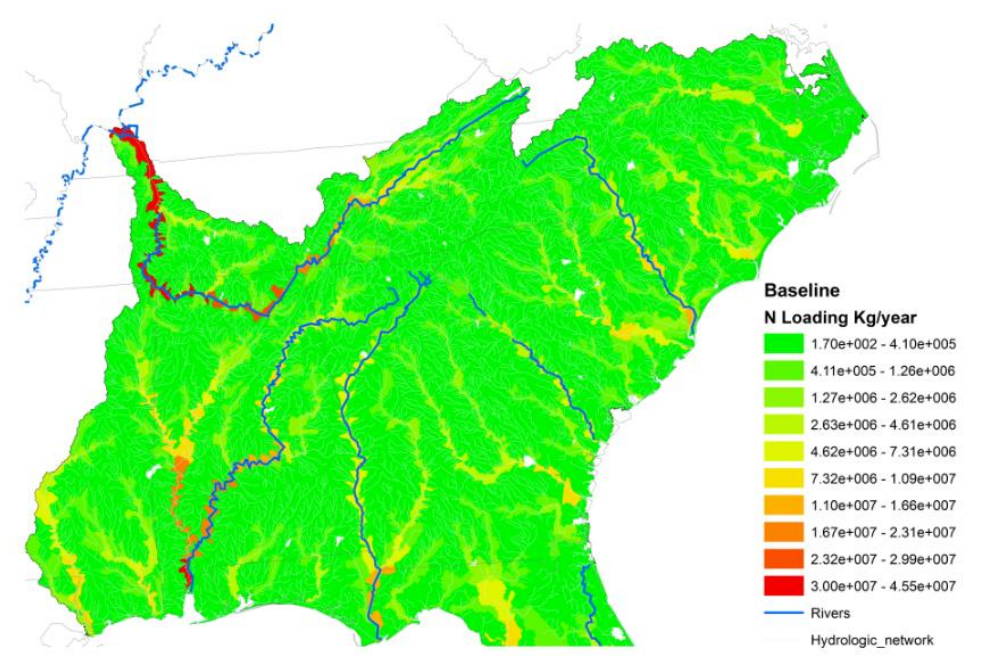

b) Calibrated baseline, N Source Share, Agriculture

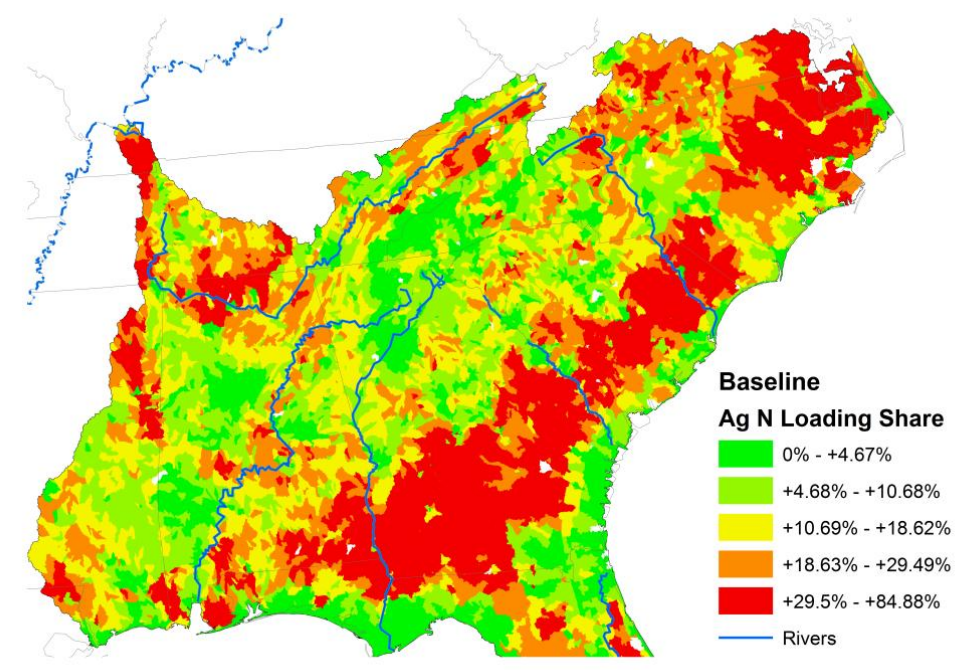

Figure 3. Baseline nitrogen loading (left panel) and commercial nitrogen source share (right panel) of calibrated Spatially Referenced Regressions on Watershed Attributes (SPARROW) model. 

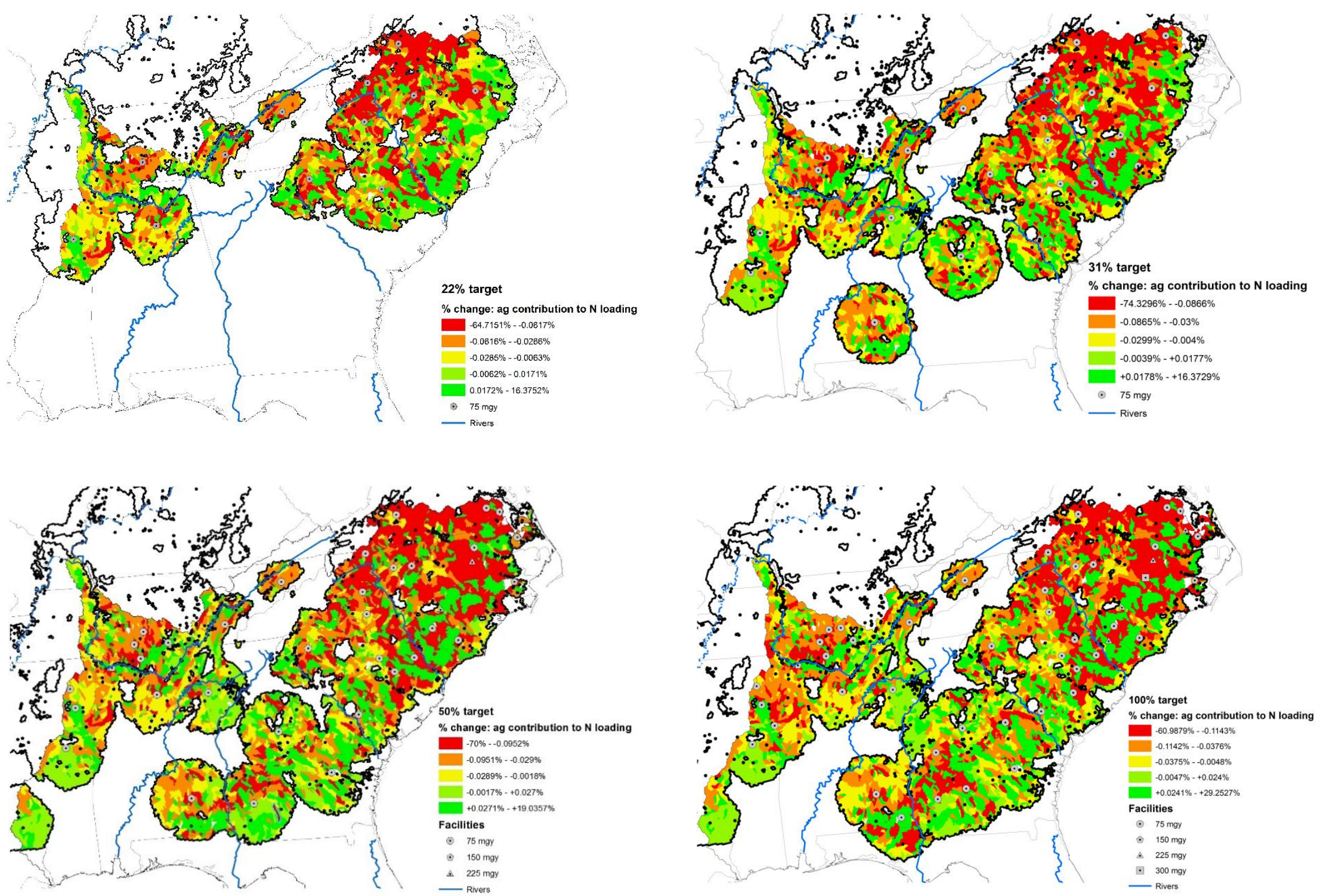

Figure 4. Change in nitrogen applied in agriculture from baseline (Figure 3b) at each target. Breaks are quintiles. 

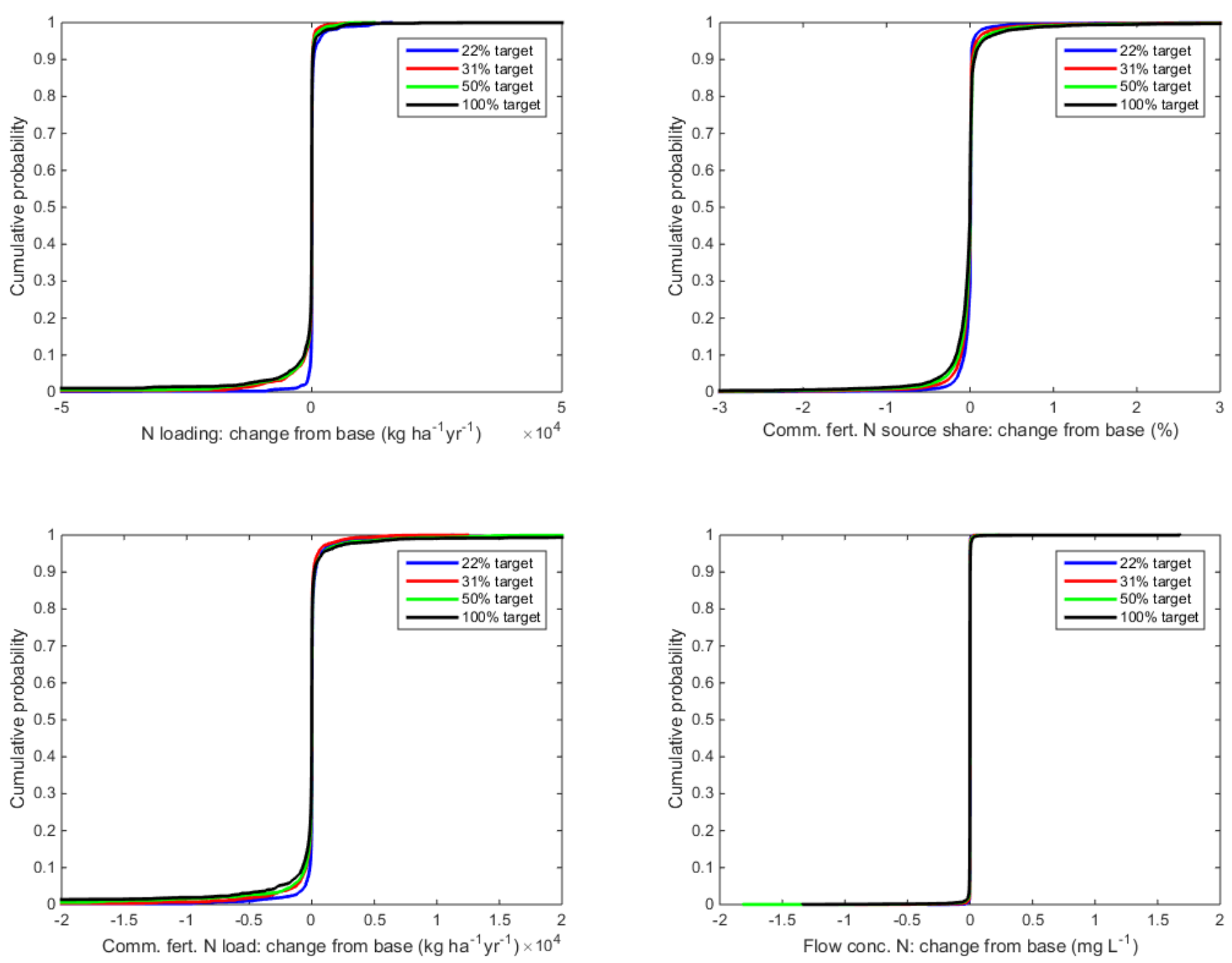

Figure 5. Empirical distributions of policy impacts on $\mathrm{N}$ loading. 

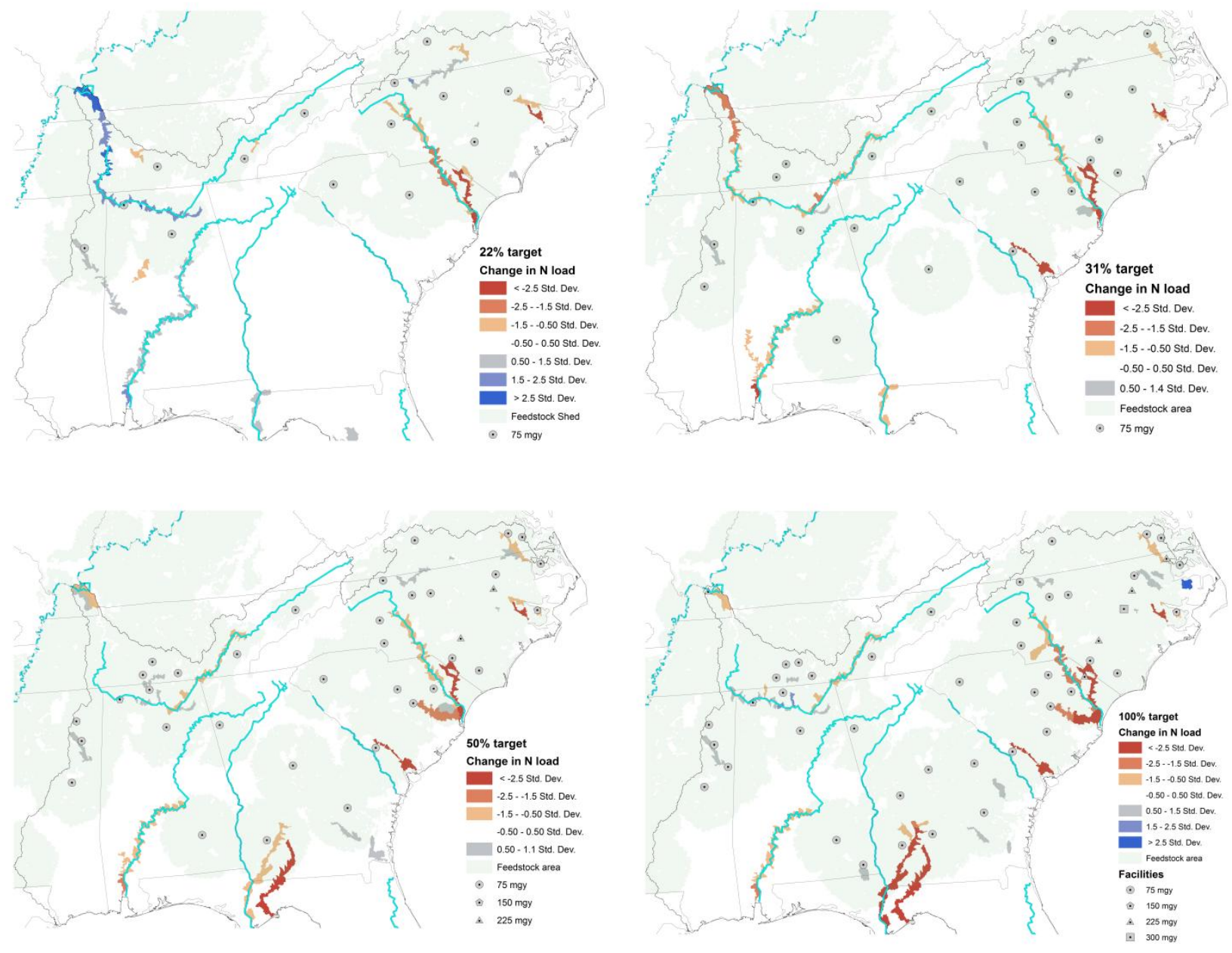

Figure 6. Change in nitrogen loading from baseline at each target. 